\title{
Fatigue resistance of endodontic instruments manufactured in NiTi CM Wire and in conventional NiTi alloy with eletrochemical treatment
}

\author{
Resistência à fadiga de instrumentos endodônticos fabricados em NiTi CM Wire e em niti convencional \\ com tratamento eletroquimico
}

Inês de Fátima de Azevedo Jacinto INOJOSA²

(iD) ORCID iD 0000-0002-0636-5321

Hélio Pereira LOPES²

(iD) ORCID iD 0000-0003-4776-1475

Phillip Lucas Ricardo PEREIRA ${ }^{1}$

(iD) ORCID iD 0000-0003-0911-4672

Diogo Lopes do NASCIMENTO'

(i) ORCID iD 0000-0002-7529-9049

Carlos Nelson ELIAS 3

(iD) ORCID iD 0000-0002-7560-6926

Victor Talarico Leal VIEIRA 4

(iD) ORCID iD 0000-0001-6434-2622

Marcia Valeria Boussada VIEIRA ${ }^{5}$

(iD) ORCID iD 0000-0003-3692-9017

\section{ABSTRACT}

\section{Objective}

This study compared the fatigue behavior of endodontic instruments manufactured with conventional NiTi alloy electropolishing, RaCe (FKG Dentaire, LaChauxdeFonds, Switzerland), with instruments manufactured with NiTi CM Wire subjected to thermomechanical treatment, in the manufacturing process, HyFlex CM (Coltène Whaledent, Cuyahoga Falls, Ohio, USA), both with similar geometry and dimensions in order to determine the influence of the manufacturing process in the fatigue resistance.

\section{Methods}

The methodoly consisted of twenty HyFlex CM and RaCe instruments with D0 $0.25 \mathrm{~mm}$, taper $0.06 \mathrm{~mm} / \mathrm{mm}, 25 \mathrm{~mm}$ length, both with triangular cross section. The fracture resistance was evaluated by static fatigue test, using a stainless artificial canal with $5 \mathrm{~mm}$ of radius $\left(86^{\circ}\right)$, recording the time and calculating the number of cycles until fracture occurs (NCF). For statistical analysis the Student $t$ test was used The fractured instruments surface was analyzed by SEM.

\section{Results}

The NCF was significantly higher for HyFlex CM instruments in comparison with RaCe files $(P<0.05)$ being $1336 \%$ more resistant to fatigue. The analysis of the fractured surface by SEM showed ductile-kind morphological characteristics for both instruments and the absence of plastic deformation.

\section{Conclusion}

HyFlex CM instruments present higher values of NCF. Thus, it can be concluded that the thermal treatment to which these instruments with CM Wire alloy are submitted makes them more resistant to fracture than Race instruments manufactured with conventional NiTi alloy electropolishing.

Indexing terms: Endodontics. Nickel. Titanium.

\section{RESUMO}

\section{Objetivo}

Este estudo comparou a vida em fadiga de instrumentos endodônticos fabricados com a liga de NiTi convencional com eletropolimento de superfície, RaCe (FKG Dentaire, LaChauxdeFonds, Suiça), com instrumentos fabricados com a liga de NiTi CM Wire, submetidos a tratamento

\footnotetext{
${ }^{1}$ Universidade Federal de Alagoas, Faculdade de Odontologia. Av. Lourival Melo Mota, s/n., Tabuleiro do Martins, 57072-900, Maceió, AL, Brasil Correspondência para / Correspondence to: IFAJ INOJOSA. E-mail: <inesjacyntho@uol.com.br>

${ }^{2}$ Universidade Estácio de Sá, Faculdade de Odontologia. Rio de Janeiro, RJ, Brasil.

${ }^{3}$ Instituto Militar de Engenharia, Engenharia Materiais, Laboratório de Biomateriais. Rio de Janeiro, RJ, Brasil.

${ }^{4}$ Universidade do Grande Rio. Rio de Janeiro, RJ, Brasil.

${ }^{5}$ Faculdades Unidas do Norte de Minas. Governador Valadares, MG, Brasil.

$\boldsymbol{\nabla} \boldsymbol{\nabla} \boldsymbol{V}$

Como citar este artigo / How to cite this article

Inojosa IFAJ, Lopes HP, Pereira PLR, Nascimento DL, Elias CN, Vieira VTL, et al. Fatigue resistance of endodontic instruments manufactured in NiTi cm wire and in conventional NiTi alloy with eletrochemical treatment. RGO, Rev Gaúch Odontol. 2018;66(2):00-00. http://dx.doi.org/10.1590/1981863720180002000013308
} 
termomecânico, no processo de fabricação, HyFlex CM (Coltene Whaledent, Cuyahoga Falls, Ohio, EUA), ambos com geometria e dimensões semelhantes, visando determinar a influência do processo de fabricação das ligas e do acabamento superficial na resistência à fadiga.

\section{Métodos}

Foram utilizados vinte instrumentos HyFlex CM e RaCe com D0 0,25mm, conicidade $0,06 \mathrm{~mm} / \mathrm{mm}$, $25 \mathrm{~mm}$ de comprimento, ambos com seção transversal triangular. A resistência à fratura foi avaliada através de teste estático de fadiga ciclica, utilizando um canal artificial em açoinoxidável com $5 \mathrm{~mm}$ de raio $\left(86^{\circ}\right)$, sendo registrado o tempo e calculado o número de ciclos para ocorrer a fratura (NCF). Para análise estatística empregou-se o teste $t$ de Student. As superfícies de fratura dos instrumentos foram analisadas em MEV.

\section{Resultados}

O NCF foi significativamente maior para os instrumentos HyFlex CM em comparacão com as limas RaCe $(p<0,05)$, sendo 1336\% mais resistentes à fadiga. A análise das superfícies fraturadas em MEV revelou características morfológicas do tipo dúctil para ambos os instrumentos e ausência de deformação plástica.

\section{Conclusão}

Os instrumentos HyFlex CM apresentaram valores mais elevados de NCF. Deste modo, pode-se concluir que o tratamento térmico a qual estes instrumentos com a liga CM Wire foram submetidos os torna mais resistentes à fratura do que os instrumentos Race, fabricados com a liga de NiTi convencional com eletropolimento.

Termos de indexação: Endodontia. Níquel. Titânio

\section{INTRODUCTION}

The use of automated nickel-titanium (NiTi) instruments has been widespread in endodontic practice due to its shape memory and superelasticity. However, the greatest concern in the use of these instruments has been the fatigue fracture in curved tooth canals [1,2]. By rotating freely in a curvature root canal, the instrument is subjected to alternating tensile and compression stresses on the outer and inner wall of the curve, respectively. These repeated cycles of stress cause cumulative microstructural changes, inducing nucleation and formation of cracks that grow, coalesce and propagate, culminating in fatigue fracture [2-5]. Fatigue resistance is concerned to the number of repeated loads (cycles) that the endodontic instrument will withstand under load until breakage occurs. The number of cycles, which is cumulative and unpredictable, is related to the intensity of the stresses imposed on the instrument and its value is obtained by multiplying the rotational speed by the time to fracturr occurs [2-5].

Several factors can influence the mechanical properties of the instruments and, therefore, the resistance to cyclic fatigue. One of these factors are the remaining defects after the machining process, such as grooves and small surface cracks, leading the instrument to fatigue rupture presenting a smaller number of cycles than expected. In order to reduce these defects, some manufacturers have used the surface electropolishing method $[6,7]$.

Recently, new manufacturing technologies with thermomechanical treatments have been developed with the aim of improving the microstructure of the alloys providing instruments with greater flexibility and resistance to fracture [8-10], such as Hyflex $\mathrm{CM}^{\circledR}$ (Coltene Whaledent, Cuyahoga Falls, $\mathrm{OH}$ ), manufactured with NiTi CM Wire alloy with controlled memory [10].

CM Wire is a new NiTi alloy introduced in Endodontics in 2010 ((DS Dental, Johnson City, TN) undergoing a special thermomechanical treatment which controls the memory of the material, making it extremely flexible, but without the shape memory of conventional Nit files. So far the manufacturing process and the heat treatment to which they are submitted have not been revealed. Hyflex $\mathrm{CM}^{\circledR}$ instruments, made with this new alloy, were marketed in 2011 and, according to the manufacturer, are $300 \%$ more resistant to fatigue than other instruments available on the market $[11,12]$.

Few studies on the mechanical behavior of NiTi CM Wire instruments in relation to the conventional NiTi instruments with eletrochemical treatment are found in the literature. The instruments 25 taper 0.06 are used to make the union of the apical and middle segments in the chemical mechanical preparation of the root canal and provide a conicity that allows an adequate irriganting flow.

The aim of this study was to compare fatigue behavior in the critical region of the instruments manufactured with CM Wire (Hyflex CM - Coltene Whaledent) and with conventional electropolishing $\mathrm{NiTi}$ alloys (Race - FKG Dentaire), with nominal diameter 25 and taper $0.06 \mathrm{~mm} / \mathrm{mm}$.

\section{METHODS}

The present study consisted of twenty NiTi engine- 
driven instruments as follows: 10 RaCe files (FKG Dentaire, La Chaux-de-Fonds, Switzerland) and 10 Hyflex CM files (Coltene Whaledent, Cuyahoga Falls, Ohio, United States). The investigated instruments presented a cross section with a triangle shape, D0 diameter of $0.25 \mathrm{~mm}$, taper 0.06 $\mathrm{mm} / \mathrm{mm}$ and $25 \mathrm{~mm}$ of total length.

\section{Fatigue test}

An artificial (Figure 1) stainless steel canal containing $1.4 \mathrm{~mm}$ of internal diameter and $19 \mathrm{~mm}$ of total length was used. The curved segment, located between two straight segments of 7 and $3 \mathrm{~mm}$, presented $9 \mathrm{~mm}$ in length, 86 degrees of curvature and a curve radius of $6 \mathrm{~mm}$ as observed in a previous study [13].

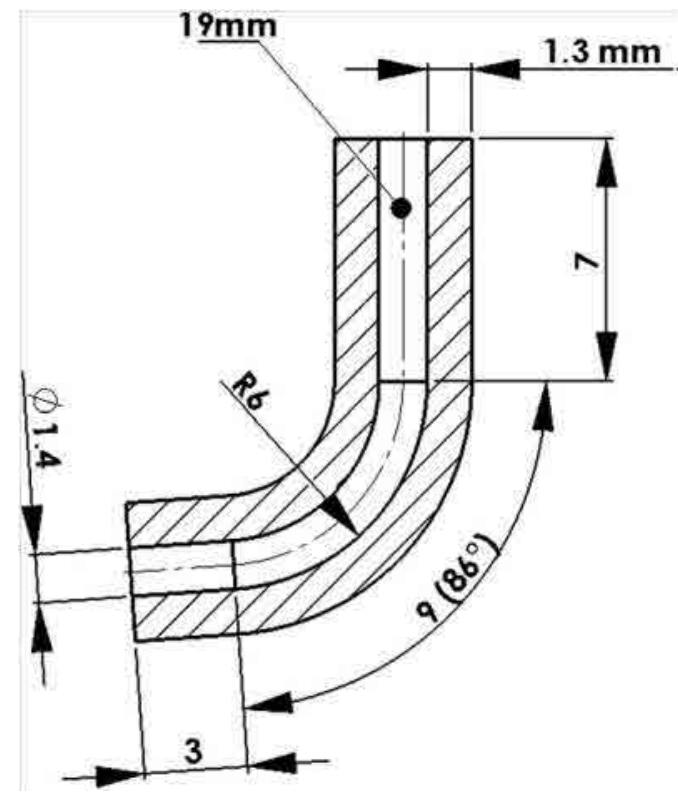

Figure 1. Drawing of the artificial canal used in the cyclic fatigue experiment.

A stainless steel device consisting of a quadrangular base and a vertical axis was used. The vertical axis contained a structure that allowed the fixation and movement of the micromotor / contra-angle. A vise was used, at the base of the device, in order to fix the artificial canal. An opening in the base of the device allowed the vise to move in a horizontal direction, causing, during the insertion of the instrument in the canal, a coincidence of the axes of the instrument with that of the straight part of the canal.
During the test, the canal was filled with glycerin in order to reduce the friction of the instrument against the canal wall and minimize the heat release. Each instrument was positioned in the contra angle / micromotor with speed reduction of 10:01 (VDW Silver, VDW, Munich, Germany) and inserted in the canal until the tip touched a bulkhead located at the end of the curved segment of the canal. This bulkhead was then removed and aimed at standardizing the penetration distance of the instrument within the canal.

Ten $\mathrm{RaCe}$ and ten Hyflex CM instruments were clockwisely rotated at a speed of $300 \mathrm{rpm}$ until fracture occurred. The time to fracture was considered according to the visual observation, being timed by the same operator, using a digital timer (Technos - Zona Franca de Manaus, Brazil).

The number of cycles for fracture (NCF) was calculated by multiplying the rotation speed by the elapsed time (in seconds) until the fracture of each instrument. The results were submitted to statistical analysis, using Student's t-test, with significance level of $5 \%$.

The fractured surfaces and helical shafts of three instruments of each group were randomly selected and analyzed by scanning electron microscopy (Jeol JSM 5800, Tokyo, Japan) in order to determine the type of fracture and the presence of plastic deformation on the shaft.

\section{RESULTS}

The time averages for fracture (in seconds) and mean number of cycles for fracture (NCF) are shown in Table 1. The Hyflex CM instruments presented higher fatigue strength than the $\mathrm{RaCe}$ instruments (p0.05).

Table 1. Mean ( \pm standard deviation) of Time (seconds) and number of cycles for fracture (NCF) of tested instruments.

\begin{tabular}{lll}
\hline & RaCe & Hyflex CM \\
\hline Time & $7.26( \pm 1.1635642)$ & $103.418( \pm 20.49834)$ \\
NCF & $36.3( \pm 5.812821)$ & $517,1( \pm 102.4917)$ \\
\hline
\end{tabular}

The scanning electron microscope (SEM), showed that the shafts near the fracture point presented ductile morphological characteristics, showing no plastic deformation of the lateral cutting edges (Figures 2 and 3). 

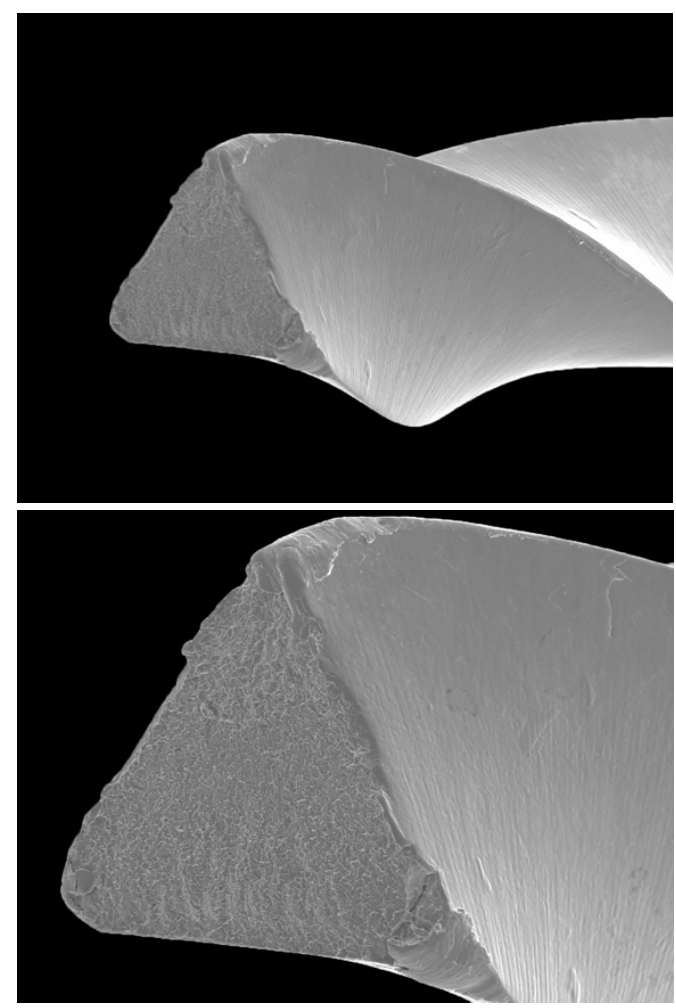

Figure 2. SEM analysis of the fractured surface of the Race file revealing absence of plastic deformation in the helical shaft.
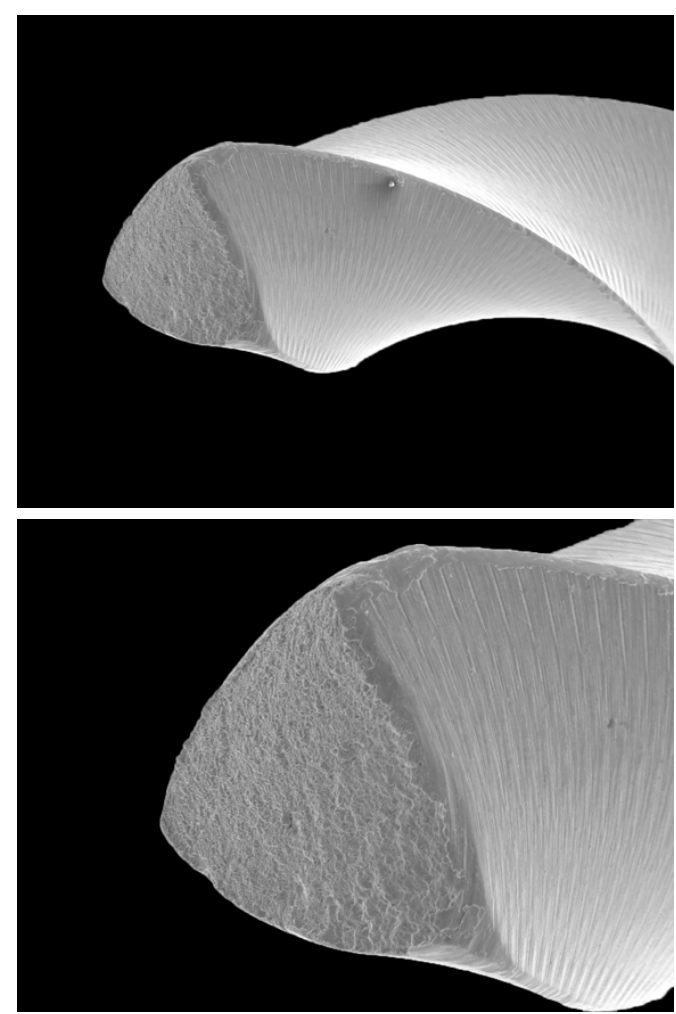

Figure 3. SEM analysis of the fractured surface of the Hyflex CM file revealing absence of plastic deformation on the helical shaft

\section{DISCUSSION}

In the present study, the results demonstrated that Hyflex CM instruments were $1336 \%$ more resistant to cyclic fatigue, presenting a statistically significant difference $(p<0.05)$ in relation to Race instruments. Considering that the instruments of this study presented the same geometric form of the cross-section, same diameter in DO and same taper, it is probable that the thermomechanical treatment realized in the NiTi CM-Wire may have favorably influenced the mechanical behavior of these new instruments

The metallic canal used in the cyclic fatigue test showed a curvature located at the transition from the apical third to the middle, allowing the analysis of which instrument would better resist fatigue in this area, making the transition between these segments safer. The taper 0.06 was chosen for irrigating substance supply and the diameter of 25 due to its wide clinical use.

Although Race instruments receive electrochemical treatment in order to reduce defects from the manufacturing process that acts as concentrators points of tension aiming at improvment in the mechanical bahavior of the same when subjected to loading, electropolishing is intended to reduce surface defects and not the internal defects [14]. Its role in increasing fatigue resistance is considered controversial, with results not always favorable $[13,15]$.

Concerning Hyflex CM instruments, a study on X-ray analysis of dispersive energy showed a lower percentage of nickel weight than the other instruments evaluated. However, thermomechanical history seems to have a much more crucial effect on mechanical strength than composition deviations [16].

Although the thermal treatment produces a better arrangement of the crystalline structure as well as modifications in the percentage of phases of the NiTi alloy, resulting in greater flexibility and better mechanical behavior, no information is given on the temperatures, duration and treatment of Hyflex CM [17]. Patented, manufacturing processes are highly influenced by temperature and time intervals, and every small change makes this manufacturing process unique and exclusive. Therefore, it is not easy to determine whether the improvement in the flexibility of the Hyflex CM instruments is due to either the unique chemical composition, the heat treatment, or both [18].

Comparative studies of endodontic instruments made with Niti CM Wire, M-Wire and conventional 
alloys have shown that the CM Wire (Hyflex CM) has greater resistance to fatigue than others, with statistically significant differences [14,19-21]. Although consistent with these results, in the present study the number of fracture cycles (NCF) was lower than that observed in most of the studies $[14,20,21]$, which can be explained by the differences in methodology used.

The fatigue test used in this sutdy was the static test and the artificial canal, although it contained a curvature radius similar to the mentioned manuscripts, presented a longer arc length, besides a severe curve, which variables may have caused the stress increase imposed on the instruments Hyflex CM, decreasing the time for fracture occurrence and consequently the NCF values.

Among the Hyflex CM instruments, it was demonstrated that those with a smaller diameter tip and lower taper showed higher NCF values in canal with $90^{\circ}$ and $5 \mathrm{~mm}$ radius [22], fact expected due to the fatigue fracture be influenced by factors such as morphology and dimensions of canals and instruments [2]. For the reasons mentioned above, the NCF results of the present study were lower than those obtained for instruments of similar size.

Due to standardization lack in the fatigue test methods of endodontic instruments, studies have used different devices and methodologies [23]. Consequently, it is of utmost importance to formulate an international standard for performing the fatigue tests of instruments working in canals, in order to obtain more reliable results.

With regard to the morphological characteristics of the fracture surface it can be fragile, characterized by a smooth, shiny or ductile surface, with presenting hemispheric dimples.

\section{REFERENCES}

1. Cheung GSP. Instrument fracture: mechanisms, removal of fragments and clinical outcomes. Endod Top J. 2009;12:1-26. doi: 10.1111/j.1601-1546.2009.00239.x

2. Pruett JP, Clement DJ, Carnes DL. Cyclic fatigue testing of nickel titanium endodontic instruments. J Endod. 1997;23(2):77-85. doi: 10.1016/S0099-2399(97)80250-6

3. Haïkel Y, Serfaty R, Baterman G, Senger B, Allemann C. Dynamic and cyclic fatigue of engine-driven rotary nickel-titanium endodontic instruments. J Endod. 1999;25(6):434-440. doi: 10.1016/S0099-2399(99)80274-X

4. Parashos $\mathrm{P}$, Messer $\mathrm{HH}$. Rotary NiTi instrument fracture and its consequences. J Endod. 2006;32(11):1031-43. doi: 10.1016/j. joen.2006.06.008
SEM analysis showed that the instruments of the study groups presented a cross section with the same triangular shape and the fracture surfaces analyzed in both instruments did not show differences in morphological characteristics; the helical shafts of the fractured instruments did not present evidence of plastic deformation; all surfaces presented morphological characteristics with the ductile fracture failure, as observed in previous studies $[5,6,13]$.

\section{CONCLUSION}

Hyflex CM instruments have shown higher NCF values than the Race instruments, representing a safer option for the chemical mechanical preparation of root canal systems that need greater taper in the apical thirds (0.06). Consequently, it can be stated that Hyflex CM instruments, manufactured with the NiTi CM Wire alloy, subjected to thermomechanical treatment are more resistant to fatigue fracture than the $\mathrm{RaCe}$ instruments, manufactured with conventional NiTi and electropolishing.

\section{Collaborators}

IFAJ INOJOSA, contributed in the writing phase of the article and statistical analysis. HP LOPES, participated in the implementation of the experimental phase and written review. PLR PEREIRA, participated in the execution of the experimental and written phase. DL NASCIMENTO, participated in the execution of the experimental and written phase. CN ELIAS, participated in the implementation of the experimental phase. VTL VIEIRA, participated in the implementation of the experimental phase and written review. MVB VIEIRA, participated in the implementation of the experimental phase.

5. Lopes HP, Ferreira AAP, Elias CN, Moreira EJ, De Oliveira JC, Siqueira JF Jr. Influence of rotational speed on the cyclic fatigue of rotary nickel-titanium endodontic instruments. J Endod. 2009 Jul;35(7):1013-6. doi: 10.1016/j.joen.2009.04.003.

6. Lopes HP, Elias CN, Vieira VTL, Moreira EJL, Marques RVL, Oliveria JCM, et al. Effects of electropolishing surface treatment on the cyclic fatigue resistance of biorace nickel-titanium rotary instruments. J Endod. 2010;36(10):1653-7. doi: 10.1016/j. joen.2010.06.026

7. Anderson ME, Price JW, Parashos P. Fracture resistance of electropolished rotary nickel-titanium endodontic instruments. J Endod. 2007;33(10):1212-6. doi: 10.1016/j. joen.2007.07.007

8. Thompson SA. An overview of nickel-titanium alloys used in dentistry. Int Endod J. 2000;33(4):297-310. doi: 10.1046/j.13652591.2000.00339.x 
9. Kuhn G, Tavernier B, Jordan L. Influence of structure on nickel-titanium endodontic instruments failure. J Endod. 2001;27(8):516-20. doi: 10.1097/00004770-20010800000005

10. Shen $Y$, Zhou $H$, Zheng $Y$, Peng $B$, Haapasalo $M$. Current challenges and concepts of the thermomechanical treatment of nickel-titanium instruments. J Endod. 2013;39(2):163-72. doi: 10.1016/j.joen.2012.11.005

11. CM Wire press release. Johnson City, TN: DS Dental; 2010.

12. ColteneEndo. HyflexCM Brochure [cited 2017 Out 2]. Available from: <http://www.hyflexcm.com/DevDownloads/HyflexCM_ brochure.pdf $>$.

13. Rodrigues RCV, Lopes HP, Elias CN, Amaral G, Vieira VTL, De Martin AS. Influence of Different Manufacturing Methods on the Cyclic Fatigue of Rotary Nickel-Titanium Endodontic Instruments. J Endod. 2011;37(11):1553-7. doi: 10.1016/j. joen.2011.08.011

14. Braga LCM, Silva ACF, Buono VTL, Bahia MGA. Impact of Heat Treatments on the Fatigue Resistance of Different Rotary Nickel-titanium Instruments. J Endod. 2014;40(9):1494-7. doi: 10.1016/j.joen.2014.03.007

15. Cheung GS, Shen Y, Darvell BW. Does electropolishing improve the low-cycle fatigue behavior of a nickel-titanium rotary instrument in hypochlorite? J Endod. 2007;33(10):1217-21. doi: 10.1016/j.joen.2007.07.022

16. Zinelis $\mathrm{S}$, Eliades $\mathrm{T}$, Eliades $\mathrm{G}$. A metallurgical characterization of ten endodontic $\mathrm{Ni}-\mathrm{Ti}$ instruments: assessing the clinical relevance of shape memory and superelastic properties of $\mathrm{Ni}-\mathrm{Ti}$ endodontic instruments. Int Endod J. 2010;43(2):125-34. doi: 10.1111/j.1365-2591.2009.01651.x

17. Shen $Y$, Zhou HM, Zheng YF, Campbell L, Peng B, Haapasalo M. Metallurgical characterization of controlled memory wire nickel-titanium rotary instruments. J Endod. 2011;37(11):156671. doi: 10.1016/j.joen.2011.08.005

18. Testarelli L, Plotino G, Al-Sudani D, Vincenzi V, Giansiracusa A, Grande Nicola $M$, et al. Bending properties of a new nickeltitanium alloy with a lower percent by weight of nickel. J Endod. 2011;37(9):1293-5. doi: 10.1016/j.joen.2011.05.023

19. Pongione G, Pompa G, Milana V, Di Carlo S, Giansiracusa A, Nicoline $E$, et al. Flexibility and resistance to cyclic fatigue of endodontic instruments made with different nickel-titanium alloys: a comparative test. Ann Stomatol (Roma). 2012;3(34):119-122.

20. Plotino G, Testarelli L, Al-Sudani D, Pongione G, Grande NM, Gambarini G. Fatigue resistance of rotary instruments manufactured using different nickel-titanium alloys: a comparative study. Odontology. 2014;102(1):31-5. doi: 10.1007/s10266-012-0088-8

21. Capar ID, ErtasH, Arslan H. Comparison of cyclic fatigue resistance of novel nickel-titanium rotary instruments. Aust Endod J. 2015;41(1):24-8. doi: 10.1111/aej.12067

22. Peters OA, Gluskin AK, Weiss RA, Han JT. An in vitro assessment of the physical properties of novel Hyflex nickel-titanium rotary instruments. Int Endod J. 2012;45(11):1027-34. doi: 10.1111/j.1365-2591.2012.02067.x

23. Plotino G, Grande NM, Cordaro M, Testarelli L, Gambarini $\mathrm{G}$. A review of cyclic fatigue testing of nickel-titanium rotary instruments. J Endod. 2009;35(11):1469-76. doi: 10.1016/j. joen.2009.06.015 